\title{
CHANGE ANALYSIS OF THE SPECTRAL CHARACTERISTICS OF RUBBER TREES AT CANOPY AND LEAF SCALES DURING THE BRAZILIAN AUTUMN
}

\author{
C. H. Amaral ${ }^{\text {a, }}$, T. I. R. Almeida ${ }^{\text {a }}$, G. C. M. Quitério ${ }^{\text {, M. M. N. Alves }}{ }^{\text {c }}$, C. R. Souza Filho ${ }^{\text {b }}$ \\ anstitute of Geosciences, University of São Paulo, Rua do Lago 562, 05508-080, São Paulo, SP, Brazil - (chamaral, \\ talmeida)@usp.br \\ ${ }^{\mathrm{b}}$ Institute of Geosciences, University of Campinas, Rua João Pandiá Calógeras 51, 13083-870, Campinas, SP, Brazil - \\ (giuliana, beto)@ige.unicamp.br \\ ${ }^{c}$ Multidisciplinary Center of Chemical, Biological and Agricultural Research, University of Campinas, P.O. BOX 6171, \\ 13081-970, Campinas, SP, Brazil - mnopper@cpqba.unicamp.br
}

Commission VIII, WG VIII/7

KEY WORDS: Forestry, spectral, weather, comparison, hyperspectral, high resolution.

\begin{abstract}
:
The objective of this work is to investigate the hyperspectral remote sensing potential to detect spectral changes undergone by clones of two rubber trees within Brazilian Autumn, with decrease of rain, temperature and photoperiod between May and June. Indirectly, we also analyze the ability of the data to help discriminating the clones at two dates in autumn. The average canopy spectra of the stands were obtained with two overpasses of the ProSpecTIR-VS airborne hyperspectral sensor (357 bands between 400-2,500 nm; spatial resolution of $1 \mathrm{~m}$ ) by $14^{\text {th }}$ May and $17^{\text {th }}$ June, in 2010 year. Additionally measurements of leaf spectra were taken in the same dates, but in the 2011 year. Considering the analysis of the spectra measured from the three stands, this indicates that spectral differences in the VIS (400-700 $\mathrm{nm}$ ) region are of genetic origin and occur regardless of environmental conditions and period of data collection. In the NIR (700-1,300 nm) range, the environmental factors predominate in the two periods of data collection. The SWIR $(1,300-2,500 \mathrm{~nm})$ displayed the largest differences between the months of data collection. In May, the relationship between stands indicated the prevalence of environmental aspects. However, in June, the stands and clones spectral behaviour indicates that as the temperature, the rainfall and the photoperiod are lower closer to winter, the SWIR can be effectively used to discriminate and map these clones separately.
\end{abstract}

\section{INTRODUCTION}

Belonging to Euphorbiaceae family, the genus Hevea, native from Amazon region presents 11 species, and its main historical-commercial representative is the Hevea brasiliensis (Wild ex Adr. de Juss) Muell-Arg. Its domestication started about 130 years ago (Gonçalves et al., 2006), although the interest in studying its cultivation within the state of São Paulo - southeast region of Brazil - aroused only in 1951 when the country started to export rubber (latex) again. Its cultivation success in the State of São Paulo - where the edaphoclimatic conditions are very different from the Amazon region (its original site), required the application of genetically improved plants as well as the test of several cultivars, such as the ones which are being studied here.

There are not many works within the literature which approach the studies of rubber trees by using remote sensing techniques. Nandris et al. (1985), when utilizing near infra-red, aimed to verify the damages caused by the parasites of rubber trees' roots in Ivory Coast. Suratman et al. (2002 and 2004), by using TM/Landsat images, aimed the attributes modeling - such as the volume, area and age - of rubber tree plantations in Malaysia. There are even other works which studied the spectral behaviour of genetic and environmental variations with species of the same genus as well as with different phenotypes of the same specie, as observed at Castro \& Sanchez-Azofeifa (2008) and at Martin \& Asner (2007) respectively. Using the ProSpecTIR-VS sensor, the same one that is used in this research, Ustin (2008) held a pioneer work on the senescence recognition of Pine's different species.

The application of field spectrometer - in order to compare and validate the spectral data obtained by imaging, and considering that there is, in these cases, influence of canopy structure, leaf angle, ligneous material and soils - is a recent accomplishment by Clark et al. (2005) and Asner \& Martin (2008), done with species of tropical rainforest. However, nothing with this approach was found in the literature for the genus Hevea.

Using hyperspectral images from the ProSpecTIR-VS airborne sensor as well as leaf measures taken from the ultraspectral ASD FiedSpec-3 Hi-Res spectrometer, the aim of this research was to verify the remote detection potential of the changes suffered by the clones late in the autumn with the drop of all: average rainfall, average temperature and photoperiod. Indirectly, we also analyze the ability of the data to help discriminating the clones at two dates in autumn.

\section{MATERIAL AND METHODS}

\subsection{Study area and object}

The study area is located at the coordinates (central) $22^{\circ} 47^{\prime}$ $52.31^{\prime \prime} \mathrm{S}$ e $47^{\circ} 6{ }^{\prime} 26.95^{\prime \prime} \mathrm{W}$, at $590 \mathrm{~m}$ above the sea, at the University of Campinas experimental farm in Paulínia city, in the State of São Paulo, southeast region of Brazil. It presents $1,972.0 \mathrm{~m}^{2}$, occupied by two stands of the PB235 clone, as well as, one stand from the GT1 clone (Figure 1). The climate for

\footnotetext{
* Corresponding author. This is useful to know for communication with the appropriate person in cases with more than one author.
} 
this region is characterized, according to Koppen classification, as Cwa-mesothermal with dry winter. Its soil is characterized as Latosolo (Oliveira et al., 1999). The area has plan topography with no soil variations, resulting in a great environmental homogeneity. Between the two dates of the study (May $14^{\text {th }}$ and June $17^{\text {th }}$ ) is observed the decrease of average rainfall $\left(21.6 \mathrm{~mm}\right.$ - last 12 years), average temperature $\left(1.0^{\circ} \mathrm{C}-\right.$ last 19 years) (CIIAGRO, 2012) and photoperiod (17.0min last year) (APOLO11, 2011).

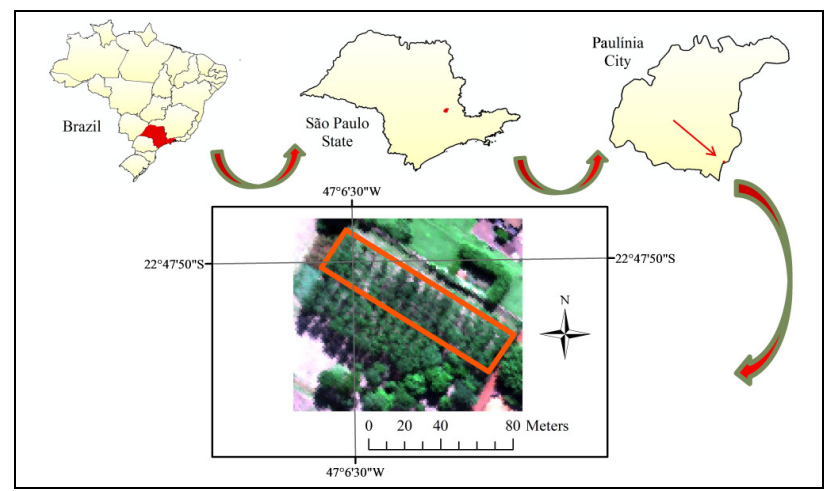

Figure 1. Study area location

Those three stands of the study area were projected with eight trees each line, $3.0 \mathrm{~m}$ spacing between trees, and $7.0 \mathrm{~m}$ line spacing, totaling 40 individuals for each stand. They were planted in 1988 and nowadays they are in maturity. According to Gonçalves (1998), the PB235 clone is a secondary Malayan clone, which is a result of the primary clones crossing - PB 5/51 $\mathrm{x}$ PB S/78. The adult trees reveal a homogenous branch formation, and the leaves are green with intense coloring. In the other hand, the GT1 clone is a primary clone developed in the rubber tree plantation called Gondang Tapen, in Java, Indonesia. The canopy opening is very late and it has a variable habit. The leaves, during the immaturity period, are big, darkgreen and bright, and are smaller when they reach the maturity period.

According to the environmental data exposed above, it is possible to observe that the only environmental heterogeneity among the studied stands is the insolation difference. The stand located near Northwest (clone PB235) is exposed to the sun in two faces, and its plantation lines, which are closer to the west, receive full lighting in the afternoon. Therefore, the stand of the GT1 clone, central, is environmentally closer to the Southeast stand of the PB235 clone. In order to distinguish the stands of the PB235 clone, the qualifications PB235-NW and PB235-SE were applied during this work.

\subsection{ProSpecTIR-VS hyperspectral sensor and processing}

The ProSpecTIR-VS sensor works using two imaging subsystems: one is in the Visible/Near infra-red region VIS/NIR (400-990nm), and the other is located in the Shortwaves infra-red region - SWIR (970 a 2,500nm), called Eagle and Hawk, respectively. This sensor, when operating in Brazil, was placed on board of SPECTIR/FOTOTERRA company's airplane. The images obtained for this research presents 357 channels, with about $5 \mathrm{~nm}$ each, distributed along the VIS/NIR (125) and SWIR (238) regions, and with $1.0 \mathrm{~m}$ of spatial resolution. The imaging process happened in May, $14^{\text {th }}$ 2010 and in June, $17^{\text {th }} 2010$. The data were delivered to the $1 \mathrm{~A}$ processing level and with UTM $23 \mathrm{~S}$ projection system and WGS 84 datum.
The reflectance images were georeferenced from their respective GLT (Geographic Lookup Table) files. Polygons were generated over the images obtained on both dates (May $14^{\text {th }}$ and June $17^{\text {th }}$ ) from the three rubber plantations' stands: PB235-NW, GT1 e PB235-SE.

Spectral libraries were created using the average behaviour of each stand for each studied date.

\subsection{ASD FieldSpec-3 Hi-Res spectrometer and processing}

The ASD FieldSpec-3 Hi-Res spectrometer detects electromagnetic radiation during the spectral interval from 350 to $2,500 \mathrm{~nm}$, and has high resolution (1,250 channels), of which 500 channels in the range from 350 to $1,000 \mathrm{~nm}$ with a $1.4 \mathrm{~nm}$ sampling interval and 750 channels that cover the range from 1,000 to $2,500 \mathrm{~nm}$, with a $2.0 \mathrm{~nm}$ sampling interval.

For the collection of the photosynthetically active leaves, one individual was selected for each plantation line and, randomly, the leaves which occupied the canopy were collected. At the research laboratory unit, we measured five leaves/tree, of which the averages spectra were extracted. This process was done one year after the images were obtained, in May $18^{\text {th }}$ and June $17^{\text {th }}$, 2011.

The average spectra for each stand and month were resampled for the 357 bands of the ProSpecTIR-VS airborne sensor.

The spectral behaviour of the targets at canopy and leaf level for May and June were compared to some spectral data generated by specialists, such as Barret (1999) and Blackburn (2007). In order to enhance the spectral differences between the clones and the stands, considering the sun exposure heterogeneity, ratios were applied between spectra.

\section{RESULTS AND DISCUSSION}

\subsection{Visible - VIS (400-700nm)}

The spectral variations in both work scales show that, between 600 and $700 \mathrm{~nm}$, the GT1 clone presented the greatest losses of $a$ and $b$ chlorophylls, from May to June (Figures 2 and 3). The spectra present significant differences, mainly in this region, once in the GT1 clone canopy, in June. In this moment the GT1 clone shows ubiquitous presence of reddish leaves with advanced senescence, highlighting the response of the carotenes with the approach of winter.

Even so in different shading conditions, in leaf scale and in this spectral region, it is possible to observe a similarity between the stands of same clone, PB235-NW and PB235-SE (Figure 3).

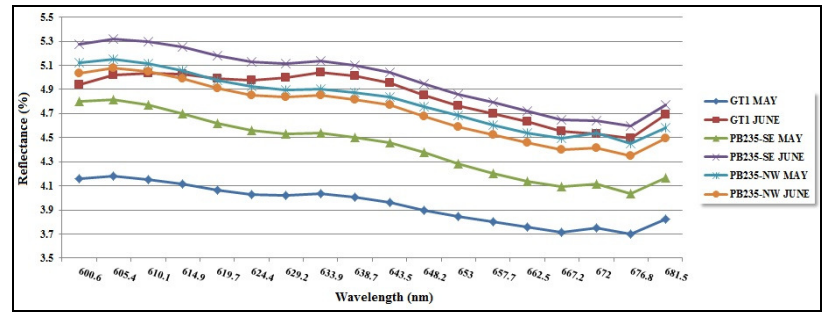

Figure 2. Spectral behaviour in canopy scale from 600 to 700nm, for May and June, of the Rubber trees stands: GT1, PB235-SE and PB235-NW 


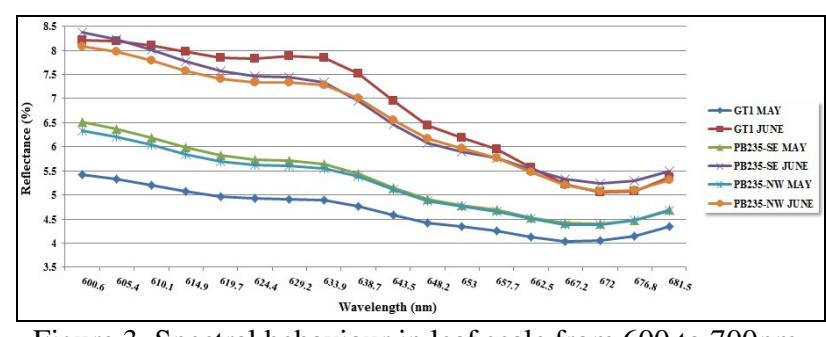

Figure 3. Spectral behaviour in leaf scale from 600 to $700 \mathrm{~nm}$, for May and June, of the Rubber trees stands: GT1, PB235-SE and PB235-NW

The carotenes, which have not been spoiled during the period, are very present on the leaves of the GT1 clone. That fact explains the maintenance of the spectral behaviour all over the blue region, from 450 to $480 \mathrm{~nm}$ (Figures 4 and 5). This spectral region coincides with the $b$ chlorophyll absorption peak, which suffered degradation, as well as it covers wide and important absorption by carotenes, mainly the photo-protectors ones.

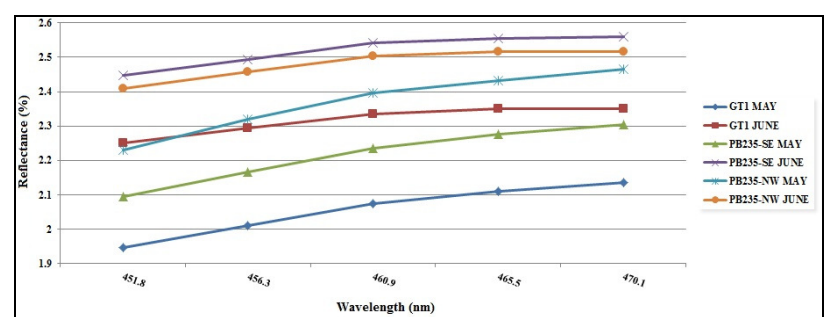

Figure 4. Spectral behaviour in canopy scale from 450 to 480nm, for May and June, of the Rubber trees stands: GT1, PB235-SE and PB235-NW

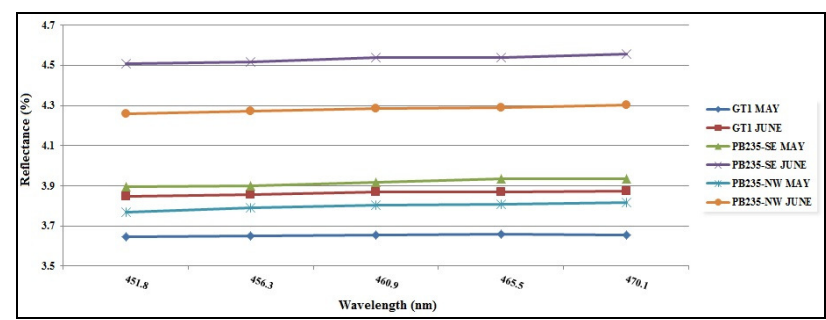

Figure 5. Spectral behaviour in leaf scale from 450 to $480 \mathrm{~nm}$, for May and June, of the Rubber trees stands: GT1, PB235-SE and PB235-NW

Around 550nm, when the anthocyanin absorption peak happens, the increase of reflectance was observed for all the three stands, exceeding for the PB235-NW stand in canopy scale (Figures 6 and 7). It is interesting to observe that this fact happened for both anthocyanin and chlorophylls and only for this stand, and in this specific scale. This spectral behaviour indicates a close relation between these compounds, what is also observed by Blackburn (2007) and Amaral et al. (2009).

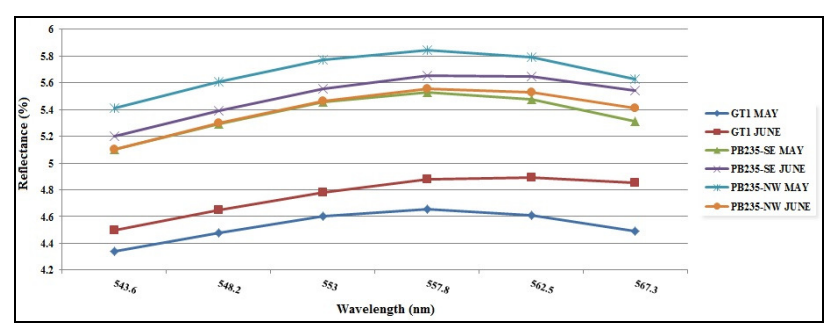

Figure 6. Spectral behaviour in canopy scale, for May and June, in the region of 550nm of the Rubber trees stands: GT1, PB235SE and PB235-NW

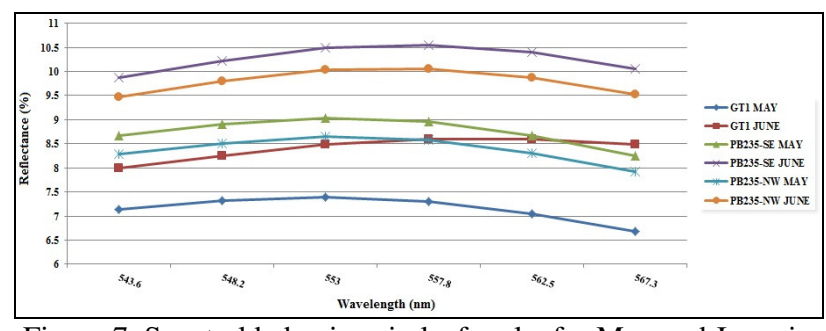

Figure 7. Spectral behaviour in leaf scale, for May and June, in the region of 550nm of the Rubber trees stands: GT1, PB235SE and PB235-NW

As it is observed in the spectral regions already presented, for the stands of the same clone, it is visible a pattern in the spectral behaviour that is different from that for GT1 clone.

The ratios among the spectra of the three stands indicated in the region VIS (400-700nm) a pattern for the stands of the PB235 clone, which differs from that for the GT1 clone (Figure 8 and 9). That demonstrates that, regardless of the environmental conditions and the period of data collection, in this spectral region, the genetic is highlighted as the origin of spectral differences. Clearly, there is a behaviour pattern among the ratios GT1/PB235-SE and GT1/PB235-NW that differs from that found among clones PB235. This behaviour is close to opposite around $550 \mathrm{~nm}$, in the May data, in leaf and canopy scales. This also happens in leaf scale around $650 \mathrm{~nm}$ and is particularly significant in June data.

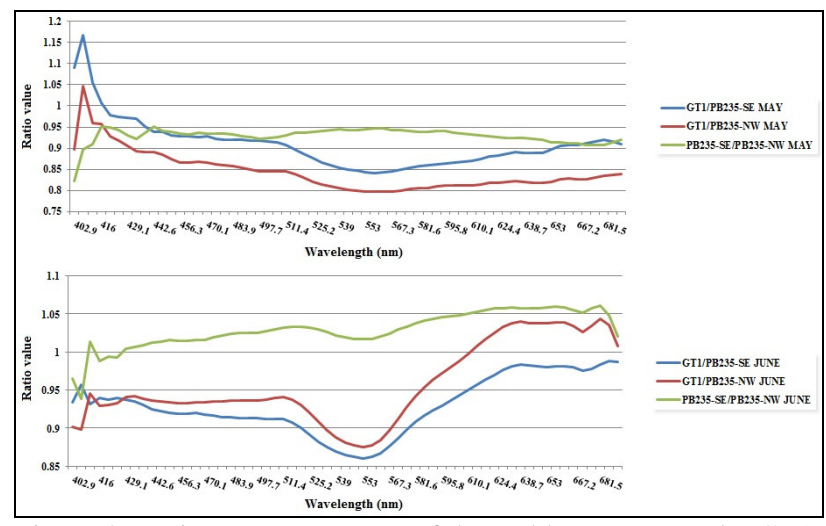

Figure 8. Ratios among spectra of the Rubber trees stands (GT1, PB235-SE and PB235-NW) from 400-700nm for May and June, in canopy scale

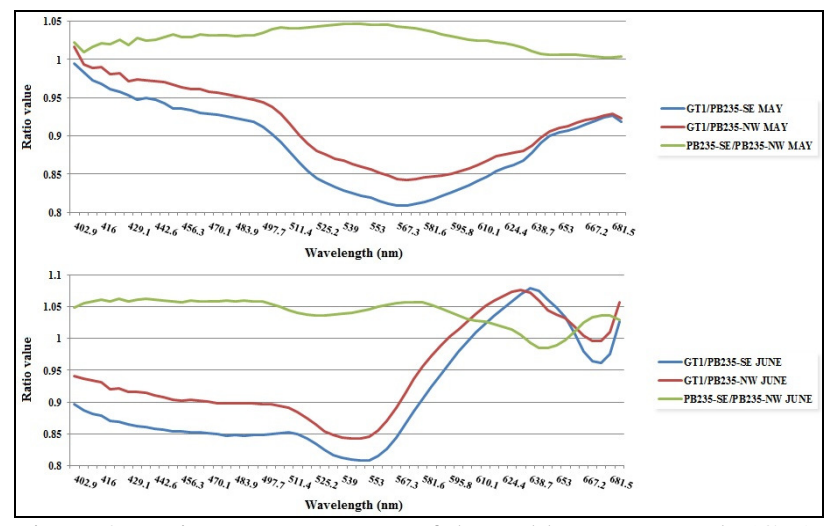

Figura 9. Ratios among spectra of the Rubber trees stands (GT1, PB235-SE and PB235-NW) from 400-700nm for May and June, in leaf scale 


\subsection{Near Infra-red - NIR (700-1,300nm)}

The evolution over time of the reflectance between the clones indicates, in contrast to VIS, a relation that is less associated with genetics than with environmental factors, restricted here to the sun exposure differences (Figure 10 and 11). The major reflectance values for the PB235-NW in both studied periods suggest a greater cutinization of the leaves and bigger thickness of their parenchyma (Jensen, 2009), considering their greater sun exposure and the tendency to leaf water loss when compared to other stands (GT1 and PB235-SE), which are more shaded. The reflectance values indicate an even greater presence of structural compounds (as lignin and cellulose) in GT1 clone, what naturally indicates genetic origin.

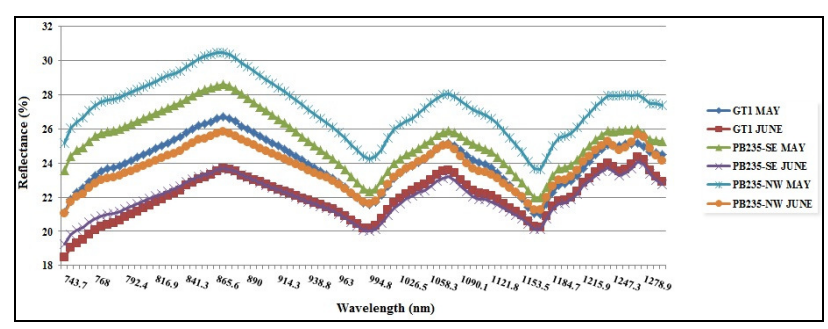

Figure 10. Spectral behaviour in canopy scale from 740 to 1,300nm, for May and June, of the Rubber trees stands: GT1, PB235-SE and PB235-NW

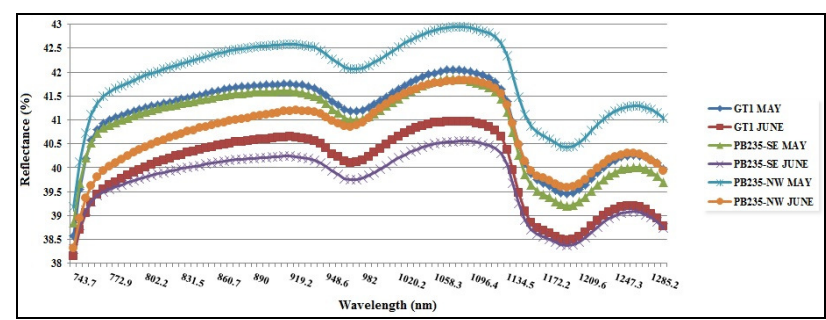

Figure 11. Spectral behaviour in leaf scale from 740 to 1,300nm, for May and June, of the Rubber trees stands: GT1, PB235-SE and PB235-NW

One of the lignin and protein absorption peak happens around $800 \mathrm{~nm}$. In this region, it was possible to observe that even though GT1 presents the greatest index of these compounds, mainly in June, the variation over the time showed a similarity of the shaded stands GT1 and PB235-SE (Figures 12 and 13). "Shade leaves" are thinnest and present smallest foliar area, if compared to "Sun leaves" (Fitter \& Hay, 2002). Those factors reduce the gaseous spaces in the interior of the leaf, evidencing the response from the structural compounds, as lignin.

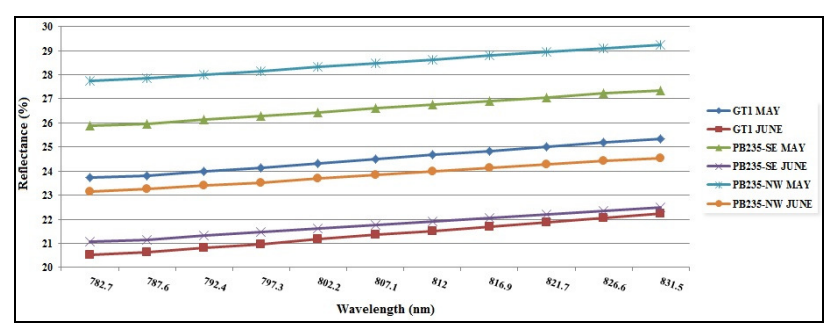

Figura 12. Spectral behaviour in canopy scale, for May and June, in the region of 800nm of Rubber trees stands: GT1, PB235-SE and PB235-NW

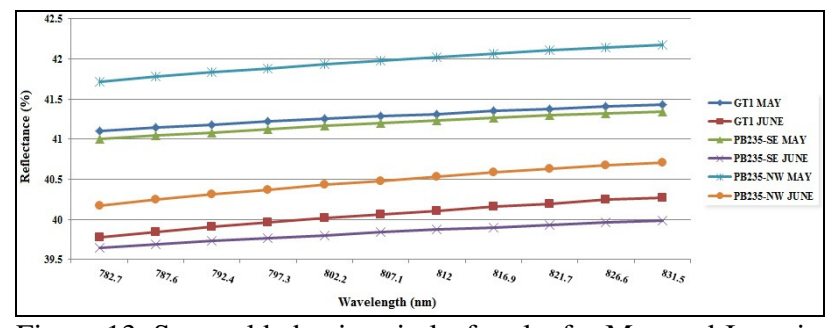

Figura 13. Spectral behaviour in leaf scale, for May and June, in the region of 800nm of the Rubber trees stands: GT1, PB235SE and PB235-NW

As observed in Figure 14, for the May data the spectral behaviour is unclear. As for June data, when the late autumn is more characteristic, the environmental similarity is imposed against the genetics. In the scale leaf (Figure 15) the environmental importance is more evident and happens indiscriminately in May and June.

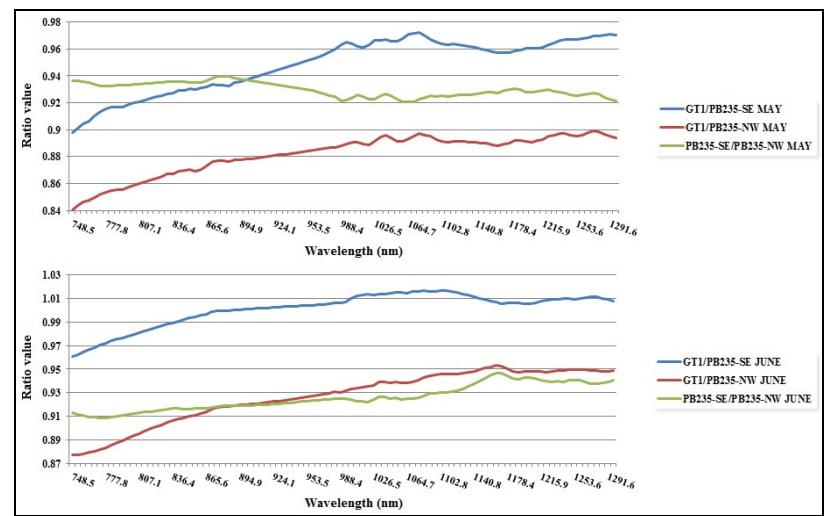

Figure 14. Ratios among spectra of the Rubber trees stands (GT1, PB235-SE and PB235-NW) from 740 to $1,300 \mathrm{~nm}$ for May and June, in canopy scale

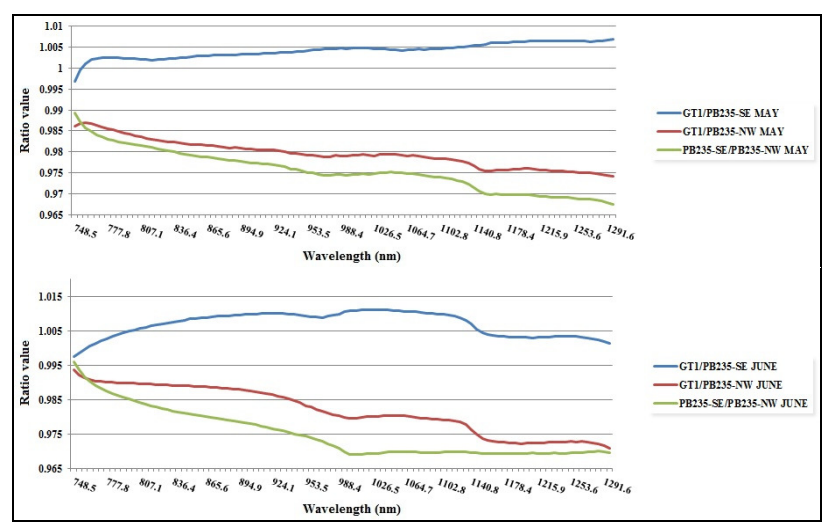

Figure 15. Ratios among spectra of the Rubber trees stands (GT1, PB235-SE and PB235-NW) from 740 to $1,300 \mathrm{~nm}$ for May and June, in leaf scale

\subsection{Shortwave Infra-red - SWIR (1,400 a 2,500nm)}

A cellulose absorption peak happens around $1,420 \mathrm{~nm}$. The data from this spectral region were obtained only in the leaf scale, once there is coincidence with the radiation absorption by the atmospheric water. It was noted that GT1 clone presents the greatest index of this compound, exceeding for May in leaf scale, when the reflectance values of the PB235-SE stands are a little lower (Figure 16). The low variation of the reflectance values of the PB235-SE stand may be explained by the fact that, as it's the most shaded stand, over the time the lighting intensity 
decrease is not able to stimulate the plasticity of thickness reduction of their leaves. Thus, as mentioned before, there is no evidence of the structural compounds by the reduction of the intercellular gaseous space, between the studied months.

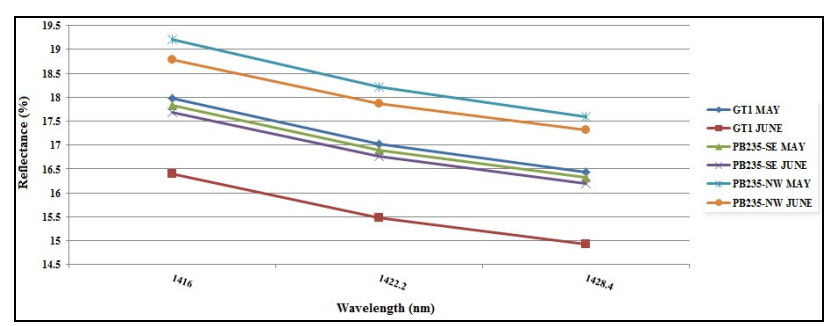

Figure 16. Spectral behaviour in leaf scale in the region 1,420nm of the Rubber trees stands: GT1, PB235-SE and PB235-NW

A more isolated absorption peak of the foliar starch, that happens around $2,220 \mathrm{~nm}$, indicated in May the lowest reflectance values for the most shaded stands (GT1 and PB235$\mathrm{SE})$. In June, even though GT1 presented the lowest values also on both scales, the PB235-NW presents, in canopy scale, the lowest values if compared to the PB235-SE. The PB235-SE was the only one to present the reduction of this compound on both scales. Although, in general terms, this compound is reserved to be consumed in stressful conditions, presenting seasonal variations and its reserve, other factors are also determinant to this compound concentration in the leaves, such as the leaf position on the branch (Dantas et al., 2007) and the period of the day (Taiz \& Zeiger, 2002). These interferences happen in a less significant way in the canopy scale, because of the leaves distribution and proximity to the imaging time (2pm and $4 \mathrm{pm}$ respectively). For this data, the variation analysis for the studied dates is simpler to read: for the leaves from the most shaded stands, where the lighting deficit is worse, it is noticed a decrease of starch concentration from May to June, indicating a greater consumption of its sugar reserves.

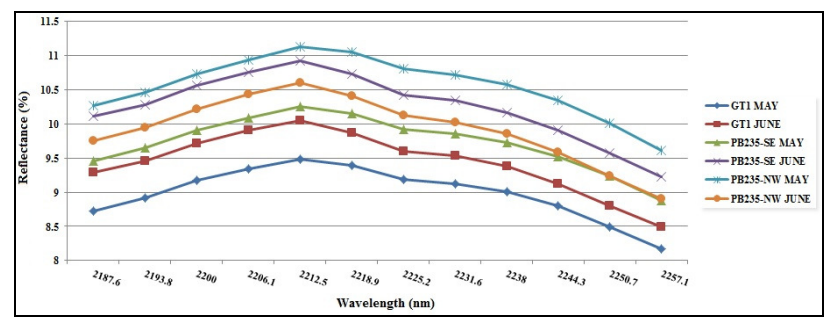

Figure 17. Spectral behaviour in canopy scale in the region 2,220nm of the Rubber trees stands: GT1, PB235-SE and PB235-NW

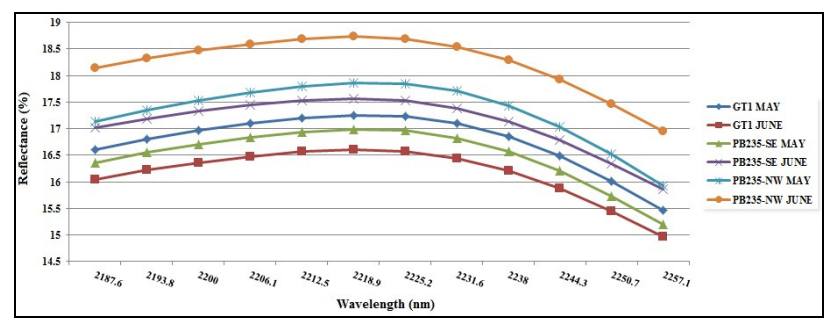

Figure 18. Spectral behaviour in leaf scale in the region 2,220nm of the Rubber trees stands: GT1, PB235-SE and PB235-NW

The SWIR was the spectral region which presented the greatest differences between the data collection dates (Figures 19 and
20). Analysing the ratios between the studied stands, in May the GT1 and PB235-SE were spectrally more similar, indicating differences from the PB235-NW one. In June, with the approach of winter, both PB235 stands started presenting similar patterns but different from the GT1. This point was found incontestable for the behaviours in leaf scale, as presented in the Figure 20.

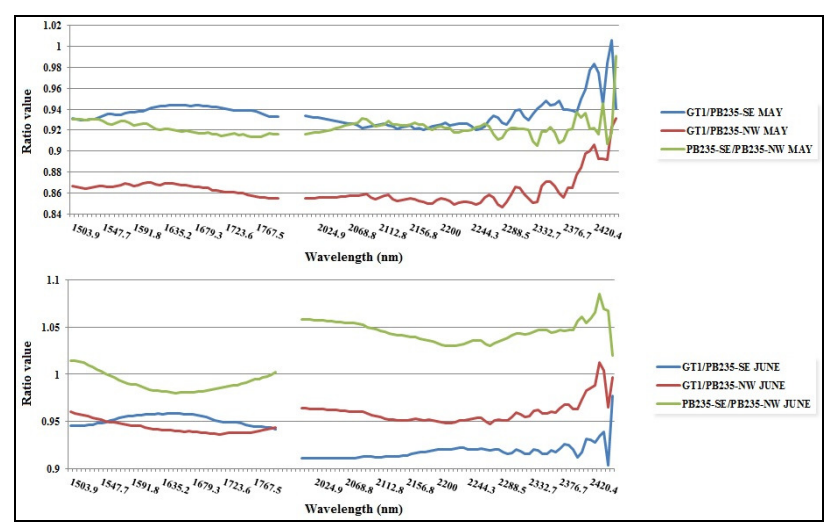

Figura 19. Ratios among spectra of the Rubber trees stands (GT1, PB235-SE and PB235-NW) from 1,300 to 2,500nm, for May and June, in canopy scale

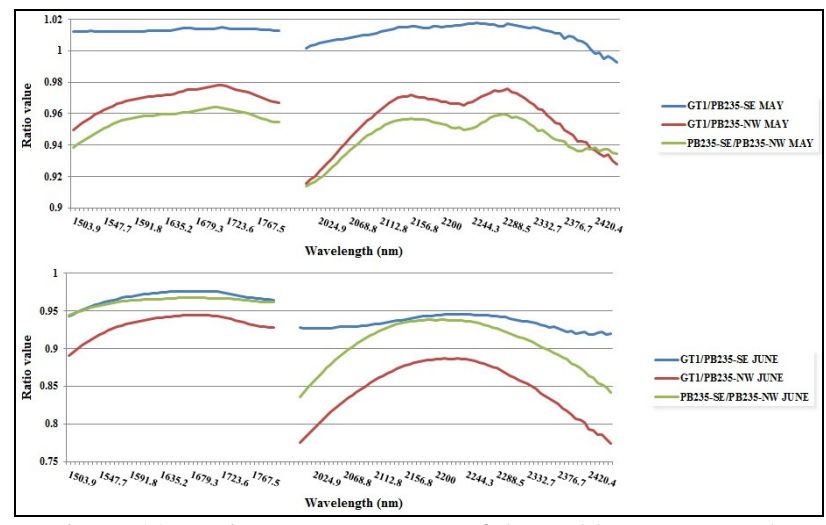

Figura 20. Ratios among spectra of the Rubber trees stands (GT1, PB235-SE and PB235-NW) from 1,300 to 2,500nm, for May and June, in leaf scale

\section{CONCLUSION}

It was possible to demonstrate the possibility of discriminating different clone of Hevea brasiliensis using the hyperspectral remote sensing, by comparing the responses of two different moments of autumn. The tool was also demonstrated to be efficient at the detection of small environmental variations. Both canopy and leaf scales had not always similar results, mainly in the SWIR. For the VIS region, mainly in June, the spectra indicate a genetic similarity regardless of the sun expose conditions.

The greatest loss of $a$ and $b$ chlorophylls suffered by GT1 clone is the main point on the clones distinction. The measures at NIR made in June, as indicators of environmental variations were noticeable and very similar in both scales. At the SWIR, it is enhanced the influence of the morphological differentiation because of the sun exposure intensity. For the stand most exposed to the sun, the parenchyma cells are more present and better developed. That explains the NIR and the SWIR behaviour by the presence of bigger intercellular gaseous space in the leaves, and at the same time, by the lower water contents considering the greater evapotranspiration of those leaves. 
The variability among the results on both leaf and canopy scales may have suffered influences by the fact that the last one comprises leaves with several levels of sun exposure and nonleaf vegetable material.

\section{REFERENCES}

Amaral, C.H., Longhitano, G. A., Almeida, T. I. R., 2009. Estudo de fisiologia da vegetação com uso de imagem hiperespectral. In: Annals of XIV Simpósio Brasileiro de Sensoriamento Remoto, Natal, Brazil, pp. 2515-2522.

APOLO 11, 2011. Lunar and solar calendar of Brazilian cities. http://www.apolo11.com/efemerides.php (15 Oct. 2011).

Asner, G.P., Martin, R.E., 2008. Spectral and chemical analysis of tropical forests: Scaling from leaf to canopy levels. Remote Sensing of Environment, 112, pp. 3958-3970.

Baret, F., 1999. Spectra of foliar pigments and biochemicals: worksheets with reflectance data. Written information sent by Frédéric Baret, INRA Avignon, France.

Blackburn, G. A., 2007. Hyperspectral remote sensing of plant pigments. Journal of Experimental Botany, 58(4), pp. 855-867.

Castro, K.L., Sanchez-Azofeifa, G.A., 2008. Changes in spectral properties, Chlorophyll content and internal mesophyll structure of senescing Populus balsimifera and Populus tremuloides leves. Sensors, 8, pp. 51-69.

CIIAGRO - Centro Integrado de Informações Agrometeorológicas (SP), 2011. Resenha agrometeorológico. http://www.ciiagro.sp.gov.br/ciiagroonline/\#Monitoramento (10 Apr. 2012).

Clark, M.L., Roberts, D.A., Clark, D.A., 2005. Hyperspectral discrimination of tropical rain forest tree species at leaf to crown scales. Remote Sensing of Environment, 96, p. 375-398.

Dantas, B. F., Ribeiro, L.S., Pereira, M. S., 2007. Teor de açúcares solúveis e insolúveis em folhe de videiras, cv. syrah, em diferentes posições no ramo e épocas do ano. Revista Brasileira de Fruticultura, 29(1), pp. 42-47.

Fitter, A.H., Hay, R.K.M., 2002. Environmental physiology of plants, 3rd ed. Academic Press, San Diego, 397 p.

Gonçalves, P. de S., 1998. Recomendação de clones de seringueira para o Estado de São Paulo. In: Annals of Ciclo de Palestras Sobre a Heveicultura Paulista, Barretos, Brazil. Vol. 1, pp. 115-140.

Gonçalves, P. de S., Aguiar, A. T. E., Gouvêa, L. R. L., 2006. Expressão fenotípica de clones de seringueira na região Noroeste do Estado de São Paulo. Bragantia, 26(3), pp.389398.

Jensen, J. R., 2009. Sensoriamento remoto do ambiente: uma perspectiva em recursos terrestres. Translated 2ed.: Epiphanio, J. C. N, Formaggio, A. R., Santos, A. R., Rudorff, B. F. T., Almeida, C. M., Galvão, L. S. Parêntese, São José dos Campos, $672 \mathrm{p}$.
Martin, R.E., G.P. Asner, Sack. L., 2007. Genetic variation in leaf pigment, optical and photosynthetic function among diverse phenotypes of Metrosideros polymorpha grown in a common garden. Oecologia, 151, pp. 387-400.

Nandris, D., Tran van Canh, J., Geiger, P., Omont, H., Nicole, M., 1985. Remote sensing in plant diseases using infrared colour aerial photography: applications trials in the Ivory Coast to root diseases of Hevea brasiliensis. European Journal of Forest Pathology, 15(1), pp. 11-21.

Oliveira, J.B.; Camargo, M.N.; Rossi, M.; Calderno Filho, B., 1999. Mapa pedológico do Estado de São Paulo. Instituto Agronômico, Campinas, Brazil, EMBRAPA-Solos, Rio de Janeiro, Brazil, Boletim Científico 45, 64 p.

Suratman, M. N., Bull, G. Q., Leckie, D. G., LeMay, V., Marshall, P. L., 2002. Modelling attributes of Rubberwood (Hevea brasiliensis) stands using spectral radiance recorded by Landsat Thematic Mapper in Malaysia. In: Geosciences and Remote Sensing Symposium - IGARSS, Toronto, Canada, Vol. 4, pp. 2087-2090.

Suratman, M. N., Bull, G. Q., Leckie, D. G., LeMay, V., Marshall, P. L., 2004. Prediction Models for Estimating the Area, Volume, and Age of Rubber (Hevea brasiliensis) Plantations in Malaysia using Landsat TM Data. International Forestry Review, 6(1), pp. 1-12.

Taiz, L., Zeiger, E., 2002. Plant physiology. 3.ed. Sinauer Associates, Sunderland, 690 p.

Ustin, S.L., 2008. Analysis of hyperspectral remote sensing to detect and map tree decline at Ft. Benning, Georgia. Army Cooperative Agreement: W912DY-06-2-0023. 33p. http://www.spectir.com/Spanish/assets/Text\%20Files/Hyperspe ctral_analysis_of_pine_decline_Ft_Benning_GA.pdf (10 Oct. 2010)

\section{ACKNOWLEDGEMENTS}

The authors would like to thank the FOTOTERRA/SpecTIR team (particularly to Guilherme Pinho and Conrad Wright) for providing the images used in the study; and Paulo de Souza Gonçalves of the Agronomic Institute (IAC) for to help in the clones discrimination in the field. FAPESP is acknowledged for the PhD grant to Cibele Hummel do Amaral (2010/51718-0). 